\title{
Growing and shrinking in the smallest tortoise, Homopus signatus signatus: the importance of rain
}

\author{
Victor J. T. Loehr · Margaretha D. Hofmeyr • \\ Brian T. Henen
}

Received: 21 November 2006 / Accepted: 21 March 2007 / Published online: 24 April 2007

(C) Springer-Verlag 2007

\begin{abstract}
Climate change models predict that the range of the world's smallest tortoise, Homopus signatus signatus, will aridify and contract in the next decades. To evaluate the effects of annual variation in rainfall on the growth of $H$. s. signatus, we recorded annual growth rates of wild individuals from spring 2000 to spring 2004. Juveniles grew faster than did adults, and females grew faster than did males. Growth correlated strongly with the amount of rain that fell during the time just before and within the growth periods. Growth rates were lowest in 2002-2003, when almost no rain fell between September 2002 and August 2003. In this period, more than 54\% of the tortoises had negative growth rates for their straight carapace length (SCL), shell height (SH), and shell volume (SV); maximum shrinking for SCL, SH, and SV was 4, 11, and $12 \%$, respectively. The shell of $H$. s. signatus has some flexibility
\end{abstract}

Communicated by Anssi Laurila.

Electronic supplementary material The online version of this article (doi:10.1007/s00442-007-0738-7) contains supplementary material, which is available to authorized users.

\section{J. T. Loehr ( $\square)$}

Homopus Research Foundation,

Kwikstaartpad 1, 3403 ZH IJsselstein, Netherlands

e-mail: loehr@homopus.org

V. J. T. Loehr · M. D. Hofmeyr · B. T. Henen

Chelonian Biodiversity and Conservation-Southern Africa,

Department of Biodiversity and Conservation Biology,

University of the Western Cape, Private Bag X17,

Bellville 7535, South Africa

\section{B. T. Henen}

Natural Resources and Environmental Affairs,

MAGTFTC Marine Corps Air Ground Combat Center,

Twentynine Palms, CA 92278-8110, USA dorso-ventrally, so a reduction in internal matter due to starvation or dehydration may have caused SH to shrink. Because the length and width of the shell seem more rigid, reversible bone resorption may have contributed to shrinkage, particularly of the shell width and plastron length. Based on growth rates for all years, female $H$. s. signatus need 11-12 years to mature, approximately twice as long as would be expected allometrically for such a small species. However, if aridification lowers average growth rates to the level of 2002-2003, females would require 30 years to mature. Additionally, aridification would lower average and maximum female size, resulting in smaller eggs and hatchlings. These projected life history responses to aridification heighten the threat posed by the predicted range contraction of this red-listed species.

Keywords Body size $\cdot$ Climate change $\cdot$ Drought . Growth rate $\cdot$ Reptile

\section{Introduction}

The tremendous variation in animal life histories reflects the complex interplay of intrinsic and extrinsic influences upon growth, reproduction, survivorship, and other life history traits. Important extrinsic determinants of growth include among others, temperature (Atkinson 1996), water availability (Lorenzon et al. 1999), food availability (Dunham 1978), and food quality (Gauthier et al. 2006). Growth, survival and reproduction are often interdependent (Ricklefs 2006; Gauthier et al. 2006), and the effect of environmental variability on these life history traits may have far-reaching consequences for population dynamics and persistence. Recent studies showed that increasing spring temperatures advanced the breeding date of tree swallows 
over North America (Dunn and Winkler 1999) but climatic variability may induce mismatches between food availability and requirements (Stenseth and Mysterud 2002), as has been shown for great tits (Visser et al. 1998). Severe winter conditions, which limit food availability, lower the growth rates of reindeer calves in Norway (Weladji and Holand 2003). To help us understand and conserve biodiversity, we must evaluate the relative impact of natural and human influences on animal life histories and populations.

Tortoises are long-lived species that grow slowly and may require more than a decade to reach sexual maturity (Germano 1994; Aresco and Guyer 1999). In reptiles, as in many animal groups, there is a positive correlation between age at maturity and longevity (Tinkle 1969; Shine and Iverson 1995), so that some costs associated with delayed maturity are offset by iteroparity (Kuchling 1999). Anthropogenic impacts, such as land development, climate change, road traffic, and collecting for consumption or the wildlife trade, challenge the success of life history strategies of tortoises, and have contributed to the current listing of 33 tortoise species (circa $60 \%$ of all tortoise species; Ernst et al. 2000) in the IUCN Red Data Book (IUCN 2006).

Given the constraints imposed by tortoise life histories, it is important to understand growth patterns and their determinants in order to facilitate conservation. Incubation temperature influences post-hatching growth rates of some chelonians (Brooks et al. 1991; Demuth 2001), but little is known about the effects of environmental conditions on growth to maturity. Although Germano (1994) concluded that interspecific differences in growth rates among Gopherus spp. were not explained by different climatic conditions among the species' ranges, growth in desert tortoises (G. agassizii) appears to be related to rainfall and primary production (Medica et al. 1975; Berry 2002). Desert tortoises respond remarkably to changing environmental conditions (Peterson 1996a, 1996b; Henen et al. 1998), but it is not known how these physiological and behavioral responses relate to growth rates.

Growth is associated with a positive increase in the size of an animal, but Galápagos marine iguanas, Amblyrhynchus cristatus, can shrink in years of food shortages (Wikelski and Thom 2000). In this species, shrinking appears to be an adaptive response to nutrient stress because individuals that shrink more have higher survivorship. A similar phenomenon has not been described for tortoises and would challenge current notions about the rigid nature of the tortoise shell.

The Namaqualand speckled tortoise, Homopus signatus signatus, is the world's smallest tortoise species (maximum straight carapace length $110 \mathrm{~mm}$; Loehr et al. 2006), and is restricted to the arid winter rainfall area of the Succulent Karoo in northwestern South Africa (Boycott and Bourquin
2000). H. s. signatus lives in rocky terrain, where it retreats in crevices (Loehr 2002a), and has a herbivorous diet (Loehr 2006). Female H. s. signatus produce one egg at a time and egg size is strongly correlated to body size and body condition (Hofmeyr et al. 2005). Body condition in turn is influenced by winter rainfall patterns (V.J.T. Loehr et al., unpublished manuscript); the rains in the austral winter fall primarily from May to August. Their relatively large eggs ( $7.5 \%$ of body size) suggest that, compared to small hatchlings, large hatchlings may survive better in their harsh environment (Hofmeyr et al. 2005). Consequently, it is important to know how long H. s. signatus females require to grow large enough to produce viable offspring. The strong effects of rainfall and body size on the reproduction of $H$. s. signatus, together with recent threats of climate change to its restricted range (Rutherford et al. 1999), make it critical to understand how the environment influences growth in $H$. s. signatus.

We measured growth of $H$. s. signatus for a total of four 12-month growth periods, from 2000 to 2004. Here we report average growth rates for males, females and juveniles, the relationship of growth rates to rainfall, and a high incidence of shrinking during a particularly dry year.

\section{Materials and methods}

A population of $H$. s. signatus near Springbok, South Africa (South African Coordinate System: Grid Cell 2917DB) was monitored annually for 5-6 weeks each spring (August-October) from 2000 to 2004 (see Loehr 2002a for a site description). Each day the study site (3.6 ha) was traversed and inspected systematically by $2-5$ experienced field workers who searched among rocks, under shrubs, and in open areas for tortoises. For each tortoise that we found for the first time in a year, we used electronic callipers to measure, to the nearest $0.01 \mathrm{~mm}$, straight carapace length (SCL, midline distance at the nuchal and supracaudal scutes), shell width (SW, where the shell was widest), shell height ( $\mathrm{SH}$, where the shell was highest), and plastron length (PL, midline distance at the gular and anal scutes). Shell volume (SV) was estimated using a modified formula for an ellipsoid ( $\mathrm{SV}=\pi \times \mathrm{SCL} \times \mathrm{SH} \times \mathrm{SW}$ / 6,000 , as $\mathrm{cm}^{3}$; Loehr et al. 2004). Our study design required repeatability of measurements throughout the study. Consequently, the senior author collected most of the data and, to minimize variance, trained field crews to collect data consistent with his method. In addition, using digital callipers helped minimize reading errors. Although it was not feasible to quantitatively assess the repeatability of our measurements, a significant variation in measurement technique would have obscured the patterns that we detected. Tortoises that were too small to sex were recorded as juveniles. 
Each individual was marked with a unique combination of black nail polish dots on the carapace (2000-2002), and from 2003 by notching marginal scutes (Cagle 1939). The Springbok weather station, $2.5 \mathrm{~km}$ north of the study site, provided rainfall data.

We compared male, female and juvenile measurements (SCL, SH, SW, PL and SV) using one-way ANOVA (data ranked when required to meet parametric assumptions). Mean growth increments or growth rates of SCL, SH, SW, PL (mm year $\left.{ }^{-1}\right)$, and SV $\left(\mathrm{cm}^{3}\right.$ year $\left.^{-1}\right)$ were calculated for each animal group, each 12-month growth period (e.g., spring 2000 to spring 2001), all groups combined and all periods pooled. Our field method represented sampling with replacement, although by capturing several males and females in more than two consecutive years we were able to use repeated-measures tests as well, albeit with greatly reduced sample sizes. We compared means among periods using ANOVA (two-way or one-way) for independent samples. We also report results from repeated-measures ANOVA (RM ANOVA), on animals captured in all five years, in the rare instances when these added significant results beyond those of standard ANOVA.

When possible, we used two-way ANOVA or two-way RM ANOVA to simultaneously test for effects of animal group and period. If the data did not meet parametric assumptions, even after log- or rank-transformations, we used one-way ANOVA or one-way RM ANOVA on raw or transformed data, and in two instances, we used non-parametric Kruskal-Wallis tests. Student-Newman-Keuls (SNK) and Dunn's post hoc tests followed parametric and nonparametric ANOVA, respectively. To determine if growth increments were significantly different from zero, we used one-sample $t$ tests, or Wilcoxon tests if samples were non-parametric. We compared frequencies of negative growth rates among periods and groups by contingency table analysis $\left(\chi^{2}\right)$

To account for body size differences in comparisons between males and females, and among growth periods, we used ANCOVA to compare linear regressions of growth increments (SCL, SH, SW and PL) on initial SCL, and growth of SV on initial SV (Zar 1999). ANCOVA was used only when regressions were statistically significant for the relevant groups or periods; in some cases log- or ranktransformation was necessary to comply with parametric assumptions. The slopes and elevations of regression lines were compared by ANCOVA (Zar 1999) followed by SNK post hoc tests for cases with more than two groups.

We assessed correlations between growth rates of the four 12-month growth periods and rainfall for the same period, that is, from September to August. However, growth in herbivores will lag behind rainfall partly due to the time required for plants to respond to rain. High rainfall towards the end of winter (July-August) would probably not affect growth before September, so we also evaluated the effects of rainfall from August to July, and from July to June, on the growth of $H$. s. signatus. Effects of the rainfall periods and body size (SCL and SV) on growth rates were evaluated by multiple regression analysis. We used ANCOVA to evaluate whether male and female growth responded similarly to variation in annual rainfall. Because body size influenced growth rates, we used ANCOVA on the residuals (Clark et al. 2001; Hofmeyr et al. 2005) of growth scaled on body size. For all correlations of growth to rainfall, data were log- or rank-transformed when data were not parametric.

Differences were considered statistically significant at $P<0.05$. We completed Wilcoxon's tests in StatsDirect 1.9.12 (Iain E. Buchan, UK), and ANCOVA, contingency table analysis and one-sample $t$ tests according to Zar (1999). All other statistics were completed in SigmaStat 2.03 (SPSS Inc., Chicago, IL, USA).

\section{Results}

Annual rainfall varied from 131 to $226 \mathrm{~mm}$, and was below average (218 mm, for 1990 to 2004) in all years except 2001 (Fig. 1). The timing of the rains differed from year to year (Fig. 1); most notably, winter rainfall was nearly absent in 2003, when $79 \%$ of the annual rainfall fell in 1 month, August. In September 2003, we noted qualitatively that few annuals had germinated and that primary production was very low. In contrast, September 2001 had extraordinarily lush vegetation. Rainfall from September to August, the periods for which we recorded $H$. s. signatus growth, was 244, 183, 150 and $94 \mathrm{~mm}$, respectively, for the four growth periods. Rainfall for August to July (1 month time lag) was 211, 200, 73, and $184 \mathrm{~mm}$, respectively, whereas rainfall was 172,268 , 92, and $162 \mathrm{~mm}$, respectively, for July to June (two-month time lag).

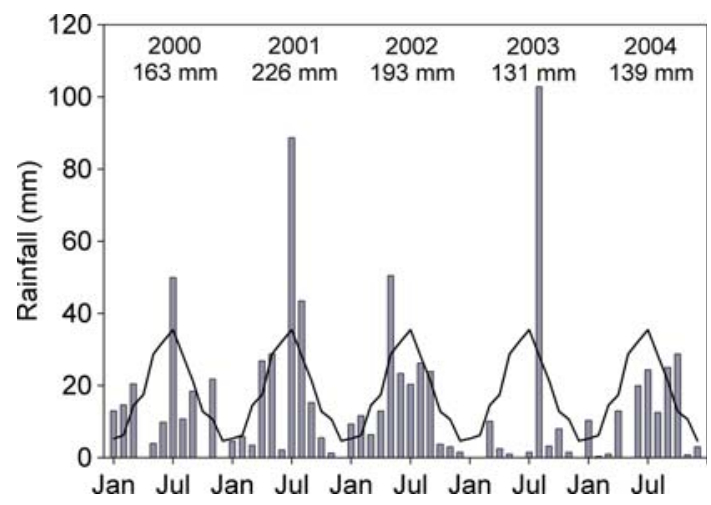

Fig. 1 Monthly rainfall from 2000 to 2004 (bars), and long-term monthly averages (1990-2004; line), for Springbok, South Africa. Annual rainfall is indicated for 2000-2004 
There was considerable variation in tortoise shell measurements (Fig. 2a) and in the annual growth increments of shell dimensions (Fig. 2b). The mean percent change ( \pm SD,$N=202$, but $N_{\mathrm{PL}}=201$ ) in shell dimensions for all tortoises, expressed relative to the value at the beginning of the 12-month periods, was $2.1 \pm 4.7 \%$ for SCL, $1.6 \pm 5.1 \%$ for $\mathrm{SH}, 2.1 \pm 3.9 \%$ for $\mathrm{SW}, 2.2 \pm 4.6 \%$ for $\mathrm{PL}$, and $6.3 \pm 13.6 \%$ for SV.

Growth variation among groups and periods

For the entire study, juvenile growth rates (in absolute terms) exceeded growth rates of adults (Fig. 2b). The exception was SV, which was similar for females and juveniles (Fig. 2b). Growth rates of male, female, and juvenile $H$. $s$. signatus differed among periods (Table 1), with 2002-2003

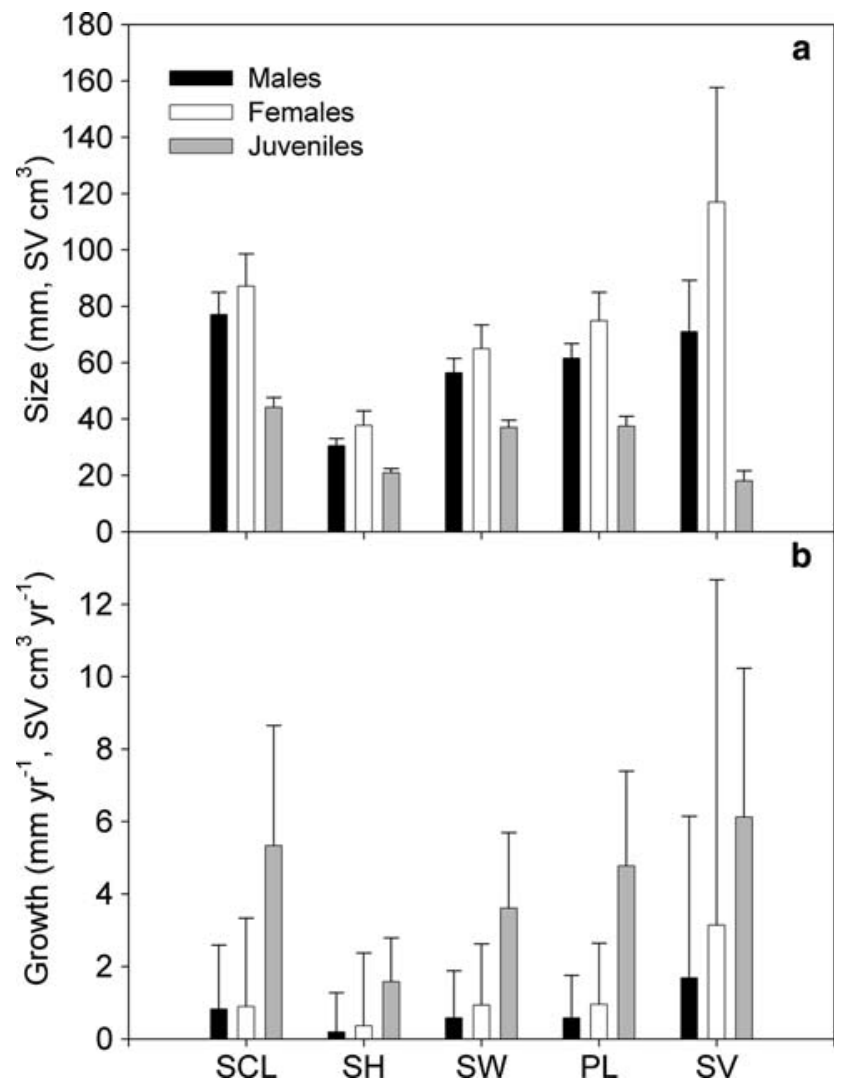

Fig. 2a-b Mean straight carapace length $(S C L)$, shell height $(S H)$, shell width $(S W)$, plastron length $(P L)$, and shell volume $(S V)$ of 51 male, 49 female, and 12 juvenile $H$. s. signatus when they were first encountered (a), and mean annual growth of these parameters (b, sample sizes in Table 1). Error bars represent standard deviations. Each shell dimension differed among groups $\left(F_{(2,109)} \geq 52.91, P<0.001\right.$; SNK: $\mathrm{F}>\mathrm{M}>\mathrm{J})$. Growth rates differed among groups for SCL, SH and PL (two-way ANOVA, $F_{(2,190)} \geq 8.82, P<0.001$ ) and for SW and SV (Kruskal-Wallis tests, $H_{2} \geq 9.16, P<0.01$ ). Juvenile growth rates were significantly higher than those for males and females, which did not differ from one another, in all parameters (SNK or Dunn's: $P<0.05$ ) except for SV, where juvenile rates were significantly greater than those of males but not females tending to have low growth rates and 2001-2002 tending to have high growth rates. Annual increments for SCL and SH were consistently lower in 2002-2003 than in any other 12month period. Male, female, and juvenile PL growth was lower in 2002-2003 than in 2001-2002. Growth of male and female SW was higher in 2001-2002 than in the other periods, while growth of juvenile SW was lower in 2002 2003 than in other periods. The increase in male and female SV was higher in 2001-2002 compared to the other growth periods. For juvenile SV, annual differences in growth were significant, but post hoc tests were not significant.

Repeated-measures analysis for males and females confirmed the differences among periods identified by independent ANOVA (two-way RM ANOVA, $F_{(3,33)} \geq 4.10$, $P \leq 0.014)$, except that $\mathrm{SH}$ increments differed between only two periods $(2002-2003<2001-2002)$, and PL growth tended to differ among growth periods $\left(F_{(3,33)}=\right.$ $2.77, P=0.057)$.

Correlations of growth with body size

The growth of all body dimensions was strongly correlated to body size for males and females (Electronic Supplementary Material, S1), but not for juveniles (all periods combined, linear regressions, $F_{(1,15)} \leq 2.19, P \geq 0.16$ ). While ANOVA did not identify growth rate differences between males and females, compensation for body size effects using ANCOVA showed that female growth rates were higher than were those of males; that is, the elevations of growth regressions (when significant for males and females) were always higher in females than in males (S1; Fig. 3a-d).

For many male and female regressions, there were differences among periods of growth, with steeper (more negative) slopes or higher elevations in 2001-2002 than in 2002-2003 (S1; Fig. 3a-d). In addition, elevations for SCL and male SV growth increments were lower in 2002-2003 than in all other 12-month periods, and elevations for male and female SV increments were higher in 2001-2002 compared to all other periods (S1). In males, SW regression elevations were higher in 2001-2002 than in 2000-2001 or 2002-2003, and the slopes of PL regressions were steeper in 2000-2001 and 2001-2002 than in 2002-2003 and 2003-2004 (S1). For some comparisons, statistical differences in elevation did not correspond to differences among intercepts (S1). This occurred because intercepts occurred outside the range of measured covariates ( $x$ values), and slight slope differences caused regression lines to cross before reaching the intercepts.

Negative growth rates or shrinking

Many H. s. signatus individuals showed negative growth rates or shrinking, but the frequency of shrinking differed 
Table 1 Variation among mean annual growth rates $\left( \pm \mathrm{SD}\right.$, range; $\mathrm{mm} \mathrm{year}^{-1}$ ) of the straight carapace length (SCL), shell height (SH), shell width (SW), plastron length (PL), and shell volume $\left(\mathrm{SV}, \mathrm{cm}^{3}\right.$ year $^{-1}$ ) of male (M), female (F), and juvenile (J) H. s. signatus

\begin{tabular}{|c|c|c|c|c|c|}
\hline & $2000-2001$ & $2001-2002$ & $2002-2003$ & 2003-2004 & Statistics \\
\hline \multicolumn{6}{|c|}{ SCL } \\
\hline M & $\begin{array}{l}1.28 \pm 1.75 \\
-0.99 \text { to } 5.00\end{array}$ & $\begin{array}{l}1.60 \pm 1.80 \\
-1.38 \text { to } 4.87\end{array}$ & $\begin{array}{l}-0.11 \pm 1.35^{\mathrm{ns}} \\
-3.39 \text { to } 3.76\end{array}$ & $\begin{array}{l}1.04 \pm 1.79 \\
-0.78 \text { to } 7.61\end{array}$ & $02-03<$ all \\
\hline $\mathrm{F}$ & $\begin{array}{l}1.13 \pm 1.99 \\
-1.07 \text { to } 6.34\end{array}$ & $\begin{array}{l}2.30 \pm 2.94 \\
-0.34 \text { to } 11.02\end{array}$ & $\begin{array}{l}-0.35 \pm 1.64^{\mathrm{ns}} \\
-3.44 \text { to } 2.84\end{array}$ & $\begin{array}{l}1.20 \pm 2.34 \\
-3.46 \text { to } 6.32\end{array}$ & $02-03<$ all \\
\hline $\mathrm{J}$ & $\begin{array}{l}9.54 \pm 2.28^{\mathrm{ns}} \\
7.92 \text { to } 11.15\end{array}$ & $\begin{array}{l}7.00 \pm 3.37 \\
3.13 \text { to } 11.55\end{array}$ & $\begin{array}{l}2.48 \pm 1.42 \\
0.59 \text { to } 4.31\end{array}$ & $\begin{array}{l}6.45 \pm 1.03 \\
5.86 \text { to } 7.64\end{array}$ & $02-03<$ all \\
\hline \multicolumn{6}{|l|}{$\mathrm{SH}$} \\
\hline M & $\begin{array}{l}0.45 \pm 1.38^{\mathrm{ns}} \\
-1.65 \text { to } 3.48\end{array}$ & $\begin{array}{l}1.01 \pm 0.86 \\
-0.43 \text { to } 2.65\end{array}$ & $\begin{array}{l}-0.50 \pm 0.80^{\text {neg }} \\
-1.89 \text { to } 1.58\end{array}$ & $\begin{array}{l}0.19 \pm 0.79^{\mathrm{ns}} \\
-1.91 \text { to } 2.10\end{array}$ & $02-03<$ all \\
\hline $\mathrm{F}$ & $\begin{array}{l}0.70 \pm 1.68^{\mathrm{ns}} \\
-1.57 \text { to } 4.17\end{array}$ & $\begin{array}{l}1.65 \pm 1.83 \\
-1.44 \text { to } 5.49\end{array}$ & $\begin{array}{l}-0.53 \pm 1.63^{\text {neg }} \\
-4.57 \text { to } 2.55\end{array}$ & $\begin{array}{l}0.16 \pm 2.27^{\mathrm{ns}} \\
-4.48 \text { to } 3.83\end{array}$ & $02-03<$ all \\
\hline $\mathrm{J}$ & $\begin{array}{l}2.10 \pm 0.55^{\mathrm{ns}} \\
1.71 \text { to } 2.49\end{array}$ & $\begin{array}{l}1.87 \pm 1.35 \\
-0.02 \text { to } 3.76\end{array}$ & $\begin{array}{l}0.78 \pm 0.98 \\
-1.17 \text { to } 1.75\end{array}$ & $\begin{array}{l}2.66 \pm 0.71 \\
1.84 \text { to } 3.14\end{array}$ & $02-03<$ all \\
\hline \multicolumn{6}{|c|}{ SW } \\
\hline M & $\begin{array}{l}0.12 \pm 1.57^{\mathrm{ns}} \\
-2.60 \text { to } 2.35\end{array}$ & $\begin{array}{l}1.51 \pm 1.09 \\
-0.37 \text { to } 4.31\end{array}$ & $\begin{array}{l}0.45 \pm 1.07 \\
-4.04 \text { to } 2.86\end{array}$ & $\begin{array}{l}0.19 \pm 1.20 \\
-4.77 \text { to } 1.86\end{array}$ & $01-02>$ all \\
\hline $\mathrm{F}$ & $\begin{array}{l}0.64 \pm 1.06 \\
-1.99 \text { to } 2.53\end{array}$ & $\begin{array}{l}2.12 \pm 2.39 \\
-0.31 \text { to } 7.90\end{array}$ & $\begin{array}{l}0.70 \pm 0.99 \\
-0.86 \text { to } 3.21\end{array}$ & $\begin{array}{l}0.23 \pm 1.39^{\mathrm{ns}} \\
-2.92 \text { to } 3.18\end{array}$ & $01-02>$ all \\
\hline $\mathrm{J}$ & $\begin{array}{l}6.36 \pm 0.07 \\
6.31 \text { to } 6.41\end{array}$ & $\begin{array}{l}5.29 \pm 1.72 \\
3.35 \text { to } 7.31\end{array}$ & $\begin{array}{l}1.73 \pm 0.69 \\
0.92 \text { to } 2.62\end{array}$ & $\begin{array}{l}3.38 \pm 0.56 \\
2.82 \text { to } 3.94\end{array}$ & $02-03<$ all \\
\hline \multicolumn{6}{|l|}{ PL } \\
\hline M & $\begin{array}{l}0.87 \pm 1.95^{\mathrm{ns}} \\
-1.45 \text { to } 6.56\end{array}$ & $\begin{array}{l}0.97 \pm 1.23 \\
-0.67 \text { to } 4.37\end{array}$ & $\begin{array}{l}0.36 \pm 0.77 \\
-0.50 \text { to } 3.62\end{array}$ & $\begin{array}{l}0.34 \pm 0.82 \\
-0.89 \text { to } 2.52\end{array}$ & $02-03<01-02$ \\
\hline F & $\begin{array}{l}0.47 \pm 1.10^{\mathrm{ns}} \\
-1.30 \text { to } 3.53\end{array}$ & $\begin{array}{l}1.94 \pm 2.52 \\
-0.13 \text { to } 9.18\end{array}$ & $\begin{array}{l}0.67 \pm 1.12 \\
-0.70 \text { to } 3.81\end{array}$ & $\begin{array}{l}0.64 \pm 1.25 \\
-0.77 \text { to } 3.65\end{array}$ & $02-03<01-02$ \\
\hline $\mathrm{J}$ & $\begin{array}{l}8.81 \pm 2.72^{\mathrm{ns}} \\
6.88 \text { to } 10.73\end{array}$ & $\begin{array}{l}6.34 \pm 1.63 \\
4.49 \text { to } 7.89\end{array}$ & $\begin{array}{l}2.53 \pm 0.99 \\
1.16 \text { to } 4.25\end{array}$ & $\begin{array}{l}4.74 \pm 1.64 \\
3.32 \text { to } 6.53\end{array}$ & $02-03<01-02$ \\
\hline SV & & & & & \\
\hline M & $\begin{array}{l}1.67 \pm 5.29^{\mathrm{ns}} \\
-5.89 \text { to } 12.10\end{array}$ & $\begin{array}{l}5.67 \pm 3.70 \\
-0.39 \text { to } 11.77\end{array}$ & $\begin{array}{l}-0.97 \pm 3.34^{\mathrm{ns}} \\
-9.85 \text { to } 5.77\end{array}$ & $\begin{array}{l}1.51 \pm 3.18 \\
-4.99 \text { to } 7.13\end{array}$ & $01-02>$ all \\
\hline $\mathrm{F}$ & $\begin{array}{l}4.47 \pm 7.18 \\
-3.87 \text { to } 15.97\end{array}$ & $\begin{array}{l}10.61 \pm 9.67 \\
-2.22 \text { to } 36.33\end{array}$ & $\begin{array}{l}-1.61 \pm 7.11^{\mathrm{ns}} \\
-24.84 \text { to } 9.85\end{array}$ & $\begin{array}{l}1.78 \pm 9.40^{\mathrm{ns}} \\
-20.11 \text { to } 16.97\end{array}$ & $01-02>$ all \\
\hline $\mathrm{J}$ & $\begin{array}{l}9.41 \pm 2.54^{\mathrm{ns}} \\
7.61 \text { to } 11.20\end{array}$ & $\begin{array}{l}8.24 \pm 5.13 \\
2.68 \text { to } 15.87\end{array}$ & $\begin{array}{l}2.81 \pm 1.82 \\
-0.38 \text { to } 5.72\end{array}$ & $\begin{array}{l}8.19 \pm 1.32 \\
6.67 \text { to } 9.02\end{array}$ & None \\
\hline
\end{tabular}

Mean growth rates were considered negative (neg), positive (no mark), or not different from zero (ns) based on single sample $t$ tests or Wilcoxon tests. The statistics column indicates significant post hoc results from ANOVA; see Fig. 2 for group effects. Interaction terms of two-way ANOVA were not significant $(P \geq 0.77)$

Two-way ANOVA, rank-transformed; SCL $F_{(3,190)}=8.25, P<0.001 ; \mathrm{SH} F_{(3,190)}=8.79, P<0.001 ;$ PL $F_{(3,189)}=2.68, P=0.048$

One-way ANOVA: SV; males $F_{(3,89)}=13.41, P<0.001$; females $F_{(3,88)}=10.07, P<0.001$; juveniles $F_{(3,12)}=4.29, P=0.026$

One-way ANOVA: SW; males (rank-transformed) $F_{(3,89)}=6.28, P<0.001$; females (log-transformed) $F_{(3,89)}=3.93, P=0.011$; juveniles (ranktransformed) $F_{(3,12)}=17.41, P<0.001$

Sample sizes for males, females, and juveniles were: 15, 14, 2 (2000-2001); 22, 23, 5 (2001-2002); 31, 34 (33 for PL), 7 (2002-2003); and 25, 21, 3 (2003-2004), respectively

among growth periods (for SCL, $\mathrm{SH}$ and $\mathrm{SV}, \chi^{2} \geq 24.24$, $d f=3, \quad P<0.001$; for $\mathrm{SW}$ and $\mathrm{PL}, \chi^{2} \geq 9.91, d f=3$, $P \leq 0.019)$. The lowest incidence of shrinking for SCL
(18\%, i.e., 9 of 50 tortoises), SH (16\%), SW (8\%), PL $(8 \%)$, and SV (10\%) occurred in 2001-2002, when average growth was positive for all body measures of all groups 
Fig. 3a-d Correlations between growth increments (SCL, $\mathbf{a}$ and $\mathbf{c} ; \mathrm{SV}, \mathbf{b}$ and $\mathbf{d}$ ) and initial body size of $H$. s. signatus for a 12-month period of good rainfall (2001-2002) and a 12-month period of very low rainfall (20022003). All regressions for males and females are significant $(F \geq 5.93, d f 1=1, d f 2 \geq 20$, $P \leq 0.024, r^{2} \geq 0.23$ ) and elevations of male regression lines are lower than those for females (ANCOVA, $t \geq 2.79, d f 1=1$, $d f 2 \geq 42, P \leq 0.0071)$. Slopes are similar $(t \leq 0.49, d f 1=1$, $d f 2 \leq 61, P \geq 0.63$ ) of male and female regressions

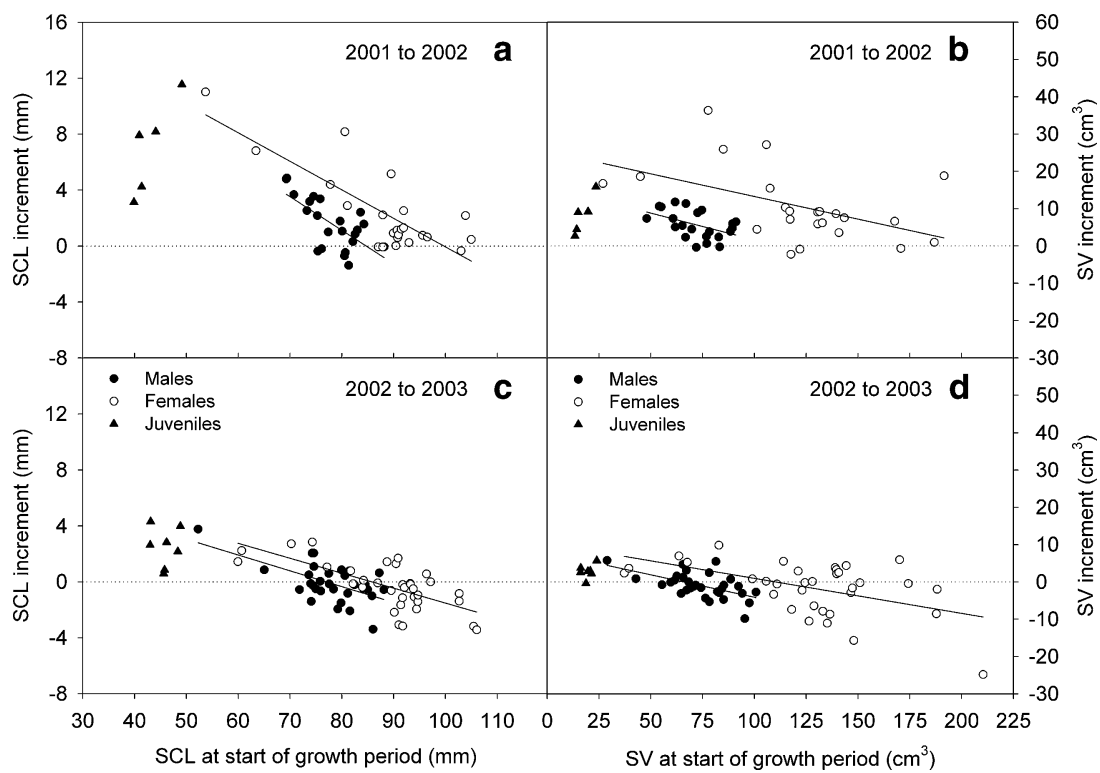

(Table 1). During this period, growth increments relative to body size differed between males and females (Fig. 3a-b) but the frequency of males and females with negative growth were similar (for all dimensions $P>0.23$ ). In fact, we recorded no sexual difference in the frequency of shrinking for any period or all periods combined $\left(\chi^{2} \leq 3.63, d f=1, P \geq 0.057\right)$.

Shrinking was very common in 2002-2003. The SCL shrank in $57 \%$ of the tortoises and growth rates (i.e., the elevations of male and female growth regressions relative to body size) were lower than in all other periods (Fig. 3cd; S1). Also, SH and SV often shrank in 2002-2003 (64 and $54 \%$ of the tortoises, respectively). Although the frequencies of SW- and PL-shrinking differed among growth periods, and were lowest in 2001-2002, the frequencies did not differ substantially among the other three periods (for SW 17-35\%, for PL 21-33\%). Juveniles rarely shrank; SH shrank for two juveniles (one in 2001-2002, one in 2002-2003), and SV shrank for one juvenile (20022003).

On average, tortoises with negative growth shrank $1 \%$ for SCL and SW, 3\% for SH, $0.5 \%$ for PL, and $3 \%$ for SV in one year. The maximum shrinkage per year was $4 \%$ for SCL, $11 \%$ for SH, $8 \%$ for SW, $2 \%$ for PL, and $12 \%$ for SV. The mean growth increment for SH during 2002-2003 was less than zero in males (one-sample $t$ tests, $t_{30}=-3.47$, $P<0.001)$ and females $\left(t_{33}=-1.88, P=0.034\right)$ (Table 1$)$.

Of all adult tortoises with SCL that shrank during 20022003, 79\% (i.e., 15 of 19 tortoises) had a positive SCL growth rate in the following year (2003-2004). Similar values for SH, SW, PL, and SV were 68, 71, 43, and 70\%, respectively. The 2003-2004 growth rates of adults that reversed negative 2002-2003 growth averaged 1.27, 1.18, 0.71 , and $0.23 \mathrm{~mm} \mathrm{year}^{-1}$ for SCL, SH, SW, and PL respectively, and $3.80 \mathrm{~cm}^{3}$ year $^{-1}$ for SV. In 2003-2004, all growth rates were larger than zero (one-sample $t$ tests, $t \geq 3.06, d f \geq 4, P \leq 0.019$; for PL $\left.t_{2}=2.88, P=0.051\right)$.

Effect of rainfall on growth rates

No growth measure for males, and few growth measures for females and juveniles, was correlated to the September to August rainfall values. Regressions included SW and SV increments for females $\left(F_{(1,90)} \geq 4.48, \quad r^{2}>0.047\right.$, $P \leq 0.037)$, and SW and PL increments for juveniles $\left(F_{(1,15)} \geq 6.77, r^{2}>0.31, P \leq 0.020\right)$.

All growth increments of males and females were correlated to the July to June rainfall $(F=4.04-40.97, d f 1=1$, $d f 2 \geq 90, r^{2}=0.04-0.31, P=0.047$ to $\left.<0.001\right)$. Most, but not all growth increments of males and females were also correlated with the August to July rainfall values $\left(F=12.98-26.44, \quad d f 1=1, \quad d f 2 \geq 90, \quad r^{2}=0.13-0.23\right.$, $P<0.001)$; the exceptions were the growth increments for $\mathrm{SW}$ and PL $(P>0.23)$. Juvenile growth was correlated to rainfall values for both periods $\left(F_{(1,15)}=6.61-31.52\right.$, $r^{2}=0.31-0.68, \quad P=0.021$ to $\left.<0.001\right)$, except for $\mathrm{SH}$ fall $\left(F_{(1,15)}=6.61, r^{2}=0.31, P=0.021\right)$.

Multiple regressions showed that body size and the Julyto-June rainfall explained $30-56 \%$ of the variation in adult growth $(F>19.40, d f 1=2, d f 2=89$ or $90, P<0.0001)$. After correcting annual growth rates for body size effects, the regression of $\mathrm{SV}$ growth on rainfall was steeper for females than for males (Fig. 4), and the regression lines intersected at a rainfall of $165 \mathrm{~mm}$ and a growth of $-0.03 \mathrm{~cm}^{3}$ year $^{-1}$. The lines for males and females intercepted zero growth at 165 and $164 \mathrm{~mm}$ rainfall, respectively. For juveniles, the combined effects of body size and growth, which was correlated only to August to July rain- 
the August-to-July rainfall values explained between 50 and $69 \%$ of the variation in growth $\left(F_{(2,14)}>7.13\right.$, $P<0.0073)$. Although growth increments of juveniles were not correlated to body size in simple regressions, $\mathrm{SH}$ and $\mathrm{SV}$ growth correlated with body size $(P \leq 0.033)$ when we accounted for the effect of annual rainfall in the multiple regression analysis.

\section{Discussion}

Growth rates of $H$. s. signatus

As in many chelonians (Kuchling 1999), growth in Homopus s. signatus is indeterminate; the high growth rate of juvenile $H$. s. signatus decreased substantially but did not stop when individuals matured. The low growth rate in adults relative to juveniles is probably associated with changes in resource allocations at maturity. In contrast to juveniles, adults invest resources in reproduction, which may limit the resources that adults have available for growth (Stearns 1992). Adult growth correlated negatively with body size, with males and females reaching maximum SCLs of 96 and $110 \mathrm{~mm}$, respectively (Loehr et al. 2006).

The growth rates (SCL) of H. s. signatus tended to be low (2.5-9.5 mm year ${ }^{-1}$ for juveniles and -0.4 to $2.3 \mathrm{~mm} \mathrm{year}^{-1}$ for adults) in comparison to other small terrestrial chelonians. Growth rates measured or modeled in Terrapene carolina bauri are about $11 \mathrm{~mm}^{\text {year }}{ }^{-1}$ at ages 0-5 years and 0.1-7 $\mathrm{mm}_{\text {year }}{ }^{-1}$ for ages 5-27 years (Ernst et al. 1998), and approximately $5 \mathrm{~mm}_{\text {year }}{ }^{-1}$ for juvenile and $0-5.1 \mathrm{~mm} \mathrm{year}^{-1}$ for adult Cuora flavomarginata

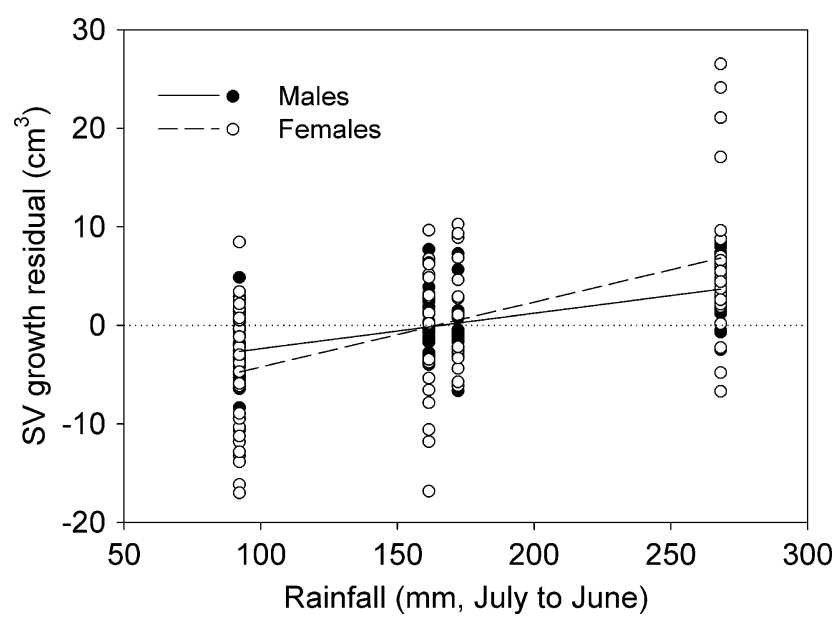

Fig. 4 Correlations between the residuals of shell volume $(S V)$ and rainfall (July-to-June) in male and female $H$. s. signatus (both $F \geq 38.34, d f 1=1, d f 2 \geq 90, P<0.001, r^{2} \geq 0.30$ ). The slope of the female regression line was steeper than the slope of the male regression line (ANCOVA, $t_{181}=2.56, P=0.011$ )
(Chen and Lue 2002). Growth rates for the tortoise Testudo horsfieldii range from 7 to $13 \mathrm{~mm} \mathrm{year}^{-1}$ for the $0-6$ year age group and 4-7 $\mathrm{mm}_{\text {year }}{ }^{-1}$ for ages 7-11 years (Lagarde et al. 2001), while in Gopherus berlandieri growth rates are about $12 \mathrm{~mm} \mathrm{year}^{-1}$ for the first 4 years and 4 $9 \mathrm{~mm}$ year $^{-1}$ for ages 5-20 years (Germano 1994). The low growth rate of $H$. s. signatus is probably associated with the small size of the species and the harsh conditions in its environment.

Female $H$. s. signatus grew faster than did males of the same size. The single, large eggs that females produce, and the strong correlation between egg size and female size, suggest a selective advantage for large eggs and offspring in H. s. signatus (Loehr et al. 2004; Hofmeyr et al. 2005). The high growth rate of females, relative to males, may facilitate females reaching their large body size and ultimately the production of large, viable eggs.

The large variation in growth within groups (see Fig. 3) suggests that some individuals were more successful than others in acquiring and allocating resources for growth. This variation may result from different availabilities of resources in microhabitats, or it may reflect inherent individual variation (genotypic or phenotypic) in the ability to gather and utilize resources from the environment. Inherent differences may provide material for selection when the environment changes.

\section{Effects of rainfall on growth}

The rainfall pattern in the habitat of $H$. s. signatus supports the growth of annual and perennial plants in autumn and winter, with most plants flowering in spring (Le Roux and Schelpe 1997; Loehr 2002b). The duration of the growth season depends on the timing of the rains, and may be long when rains start in autumn, or brief when rains start in midwinter (Van Rooyen 1999). In September 2003, when the first significant rains had fallen late, we noticed little plant growth, including known food plants for $H$. s. signatus (Loehr 2002b; Loehr 2006), whereas the field site was covered by flowering annuals in September-October 2001 after regular rain showers since autumn. The amount and timing of rainfall would influence foraging opportunities of herbivores, particularly animals such as tortoises, which rely mainly on herbaceous plants (Boycott and Bourquin 2000).

Growth rates appeared to lag behind rainfall events. $H$. $s$. signatus growth rates correlated with the amount of rain that fell just before and during the September to August growth periods. The high growth rate of $H$. s. signatus in 2001-2002 corresponds with good rains in late-winter 2001, which were followed by regular showers up to September 2002. In contrast, the extended drought from October 2002 to July 2003 explains the low growth rate in 2002-2003. The high rainfall of August 2003 was too late 
to influence growth measured in September 2003, but it influenced growth measured for 2003-2004. This delayed effect of rainfall on tortoise growth is substantiated by the higher growth rate, despite a lower rainfall during the growth period in 2003-2004 compared to 2002-2003.

The effect of rainfall on SV growth was more pronounced in females than in males. In years with low rainfall, the growth rate of females decreased more than did male growth rate, and in years with higher rainfall, female growth rate increased more than did the growth rate of males (Fig. 4). A large proportion of females was gravid each year (V.J.T. Loehr et al., unpublished data), and the different effect of rainfall on the sexes probably reflects differences between male and female investments in reproduction; females tend to allocate more towards reproduction in wet years than in dry years (Henen 1997; Grant et al. 2000). In dry years, female $H$. s. signatus appear to invest most of their resources into egg production, at the cost of growth, while in years with higher rainfall, females have sufficient resources to channel towards egg production and growth.

\section{Shrinking}

Negative growth rates or shrinking occurred on a large scale in $H$. s. signatus, and was not just an aberration involving a few individuals. There was large interindividual variation in growth, which was partly due to body size differences, with juveniles being less prone to shrinking than were adults. Because of their small size, juveniles would have had lower total energy needs than adults, which may have allowed juveniles to grow better than adults did when resources were scarce. Additionally, juveniles probably had large somatic allocations, and little if any reproductive allocations, compared to adults. In adults, shrinking was not caused strictly by nutrient allocations to egg production, as we found no differences in the frequency of shrinking between males and females. The highest incidence of shrinking coincided with an extended drought (2002-2003), when most adult $H$. s. signatus shrank instead of grew. Nevertheless, there were incidences of shrinking in all the years, even when rainfall for the period was above average (i.e., 2001-2002). It thus appears that some variation in the growth rate of $H$. s. signatus can be ascribed to different capabilities of individuals to accrue resources for growth.

The marine iguanid Amblyrhynchus cristatus may shrink up to $20 \%$ (snout-to-vent length, SVL) within two years (Wikelski and Thom 2000). Snout-to-vent length in lizards is determined by the compositions of various tissues, such as bone and connective tissue, and shrinking in A. cristatus has been ascribed to the resorption of both soft tissue and bone. In tortoises, body size is determined by the bony shell, which is covered by a thin epidermal, horny surface
(Kuchling 1999). In H. s. signatus, the bony layer of the carapace is thin, possibly to facilitate mobility in their rocky habitat, and the shell has some flexibility in the dorso-ventral plane $(\mathrm{SH})$. Females require kinesis of the posterior shell elements to pass their large egg (Hofmeyr et al. 2005), and ontogenetic replacement of bony sutures with fibrous connections, as in the freshwater terrapin Dogania subplana (Pritchard 1993), may play a role in shell kinesis and shell flexibility in $H$. s. signatus.

The maximum annual SH loss $(11 \%)$ of $H$. s. signatus was comparable to SVL shrinking in A. cristatus. A reduction in the internal mass of the tortoises (e.g., bladder and gut content, body reserves, and reproductive mass in females) probably contributed greatly to shrinking in $\mathrm{SH}$, and through the effect on SH, to shrinking of SV. The effect of shrinking was less pronounced on SCL, SW, and PL, and body shape changes due to internal mass changes may partly explain reductions in these measures. However, the shell of $H$. s. signatus is fairly rigid in width and length (particularly PL; V.J.T. Loehr et al., personal observation), suggesting that a loss of bone tissue is involved in the shrinking, as proposed for A. cristatus (Wikelski and Thom 2000).

Shrinking in $H$. s. signatus was reversible, as in marine iguanas. Wikelski and Thom (2000) viewed shrinking in marine iguanas as an adaptive response to low food availability in El Niño years because big adults that shrank more lived longer. Recent information for adult desert tortoises (G. agassizii) indicates that carapace length can shrink $0.8 \%$ (ca. $1.9 \mathrm{~mm}$ ) during a drought year (ca. 115 days of the activity period), and that this shrinkage was reversible (K.J. Field, personal communication; Field et al. 2007). We do not have sufficient data on survivorship for $H$. s. signatus, but the growth subsequent to shrinking suggests that shrinking is a reversible effect of starvation.

\section{Implications for conservation}

Based on average growth rates and regressions for SCL in juvenile and female $H$. s. signatus, we estimate that females mature in 11-12 years (assuming a hatchling SCL of $33.8 \mathrm{~mm}$, and a SCL at maturity of $84.1 \mathrm{~mm}$; Loehr 1999; Loehr et al. 2004). This period is unusually long; a chelonian the size of $H$. s. signatus would be expected to mature in approximately 5.5 years according to data for 35 chelonian species (Iverson 1992). The limited resource availability of the Succulent Karoo probably limits the tortoises' growth rate and requires that females reach a relatively large size to produce viable offspring, the combination helping explain the long growth trajectory of $H$. s. signatus.

Climate models predict that the range of $H$. s. signatus will become substantially drier within the next 50 100 years (Rutherford et al. 1999), a scenario that holds 
serious consequences for this species. Based on the low growth rates of 2002-2003, H. s. signatus females may require up to 30 years to reach sexual maturity. Additionally, the SCL growth rate of females in 2002-2003 approached zero at SCL $86 \mathrm{~mm}$, indicating that prolonged aridity would decrease the average and maximum size of females. Smaller individuals may be more vulnerable in the drier climate.

Shrinking may affect egg size and ultimately hatchling size of this species. Females that shrank in 2002-2003 produced smaller eggs (egg volume) in 2003 than in 2002 (paired $t$ test $t_{6}=2.39, P=0.054$; V.J.T. Loehr et al., unpublished data). Egg volume is correlated to SCL in $H$. $s$. signatus $\left(\mathrm{EV}=0.19 \mathrm{SCL}-6.6\right.$, in $\mathrm{cm}^{3}$; Hofmeyr et al. 2005) and the egg volume $\left(10.99 \mathrm{~cm}^{3}\right)$ of an average sized female $(92.6 \mathrm{~mm})$ would decrease by 1 or $6 \%$, respectively, when applying the average or maximum SCL shrinking rates for the dry year (2002-2003; see Table 1). In contrast, after maximum growth in a good year (2001-2002), egg volume would increase by $11 \%$, so that the maximum difference in egg volume between a good and a bad year would be $17 \%$. These egg sizes correspond to hatchling volumes of 8.05 and $9.74 \mathrm{~cm}^{3}$, a difference of $21 \%$ (V.J.T. Loehr, unpublished data from captivity).

Aridification of $H$. s. signatus' habitat would impact the time hatchlings need to reach maturity, the size of females, the size of eggs and hatchlings, and probably the success of the eggs and hatchlings. Apart from the projected effects of aridification on the life history of $H$. s. signatus, climate change models predict that $H$. s. signatus will experience a range contraction and range displacement of more than $50 \%$ over the next few decades (Erasmus et al. 2002). The prospects for $H$. s. signatus appear dire, and concerted conservation efforts are required to safeguard the future existence of the world's smallest tortoise.

Acknowledgments This study was permitted by Northern Cape Nature Conservation (permit numbers 137/99, 019/2001, 152/2002, 168/2003, 158/2003, 633/2003), the UWC Research Ethics Committee, and complies with the current laws of South Africa. Sincere thanks are extended to all field assistants, and to K.J. Field, who provided unpublished information regarding shrinking in desert tortoises. The project would not have been possible without the financial support of Royal Society of London, the National Research Foundation of South Africa, University of the Western Cape, Chelonian Research Foundation (Linnaeus Fund), Dutch Foundation for the Advancement of Herpetology, and various turtle societies and private enthusiasts.

\section{References}

Aresco MJ, Guyer C (1999) Growth of the tortoise Gopherus polyphe$m u s$ in slash pine plantations of south-central Alabama. Herpetologica 55:499-506

Atkinson D (1996) Ectotherm life history responses to developmental temperature. In: Johnston IA, Bennett AF (eds) Animals and temperature: phenotypic and evolutionary adaptation. Cambridge University Press, Cambridge, pp 183-204

Berry KH (2002) Using growth ring counts to age juvenile desert tortoises (Gopherus agassizii) in the wild. Chelonian Conserv Biol 4:416-424

Boycott R, Bourquin O (2000) The Southern African tortoise book: a guide to Southern African tortoises, terrapins and turtles. Privately printed, Hilton

Brooks RJ, Bobyn ML, Galbraith DA, Layfield JA, Nancekivell EG (1991) Maternal and environmental influences on growth and survival of embryonic and hatchling snapping turtles (Chelydra serpentina). Can J Zool 69:2667-2676

Cagle FR (1939) A system of marking turtles for future identification. Copeia 1939:170-173

Chen TH, Lue KY (2002) Growth patterns of the yellow-margined box turtle (Cuora flavomarginata) in northern Taiwan. J Herpetol 36:201-208

Clark PJ, Ewert MA, Nelson CE (2001) Physical apertures as constraints on egg size and shape in the common musk turtle, Sternotherus odoratus. Funct Ecol 15:70-77

Demuth JP (2001) The effects of constant and fluctuating incubation temperatures on sex determination, growth, and performance in the tortoise Gopherus polyphemus. Can J Zool 79:1609-1620

Dunham AE (1978) Food availability as a proximate factor influencing individual growth rates in the iguanid lizard Sceloporus merriami. Ecology 59:770-778

Dunn PO, Winkler DW (1999) Climate change has affected the breeding date of tree swallows throughout North America. Proc R Soc Lond B 266:2487-2490

Erasmus BFN, Van Jaarsveld AS, Chown SL, Kshatriya M, Wessels KJ (2002) Vulnerability of South African animal taxa to climate change. Glob Change Biol 8:679-693

Ernst CH, Altenburg RGM, Barbour RW (2000) Turtles of the world (World Biodiversity Database CD-ROM Series; Windows version 1.2). Springer Verlag/UNESCO, Heidelberg

Ernst CH, Wilgenbusch JC, Boucher TP, Sekscienski SW (1998) Growth, allometry and sexual dimorphism in the Florida box turtle, Terrapene carolina bauri. Herpetol J 8:72-78

Field KJ, Tracy CR, Medica PA, Marlow RW, Corn PS (2007) Return to the wild: Translocation as a tool in conservation of the desert tortoise (Gopherus agassizii). Biol Conserv (in press) DOI 10.1016/j.biocon.2006.11.022

Gauthier G, Fournier F, Larochelle J (2006) The effect of environmental conditions on early growth in geese. Acta Zool Sin 52:670-674

Germano DJ (1994) Growth and age at maturity of North-American tortoises in relation to regional climates. Can J Zool 72:918-931

Grant PR, Grant BR, Keller LF, Petren K (2000) Effects of El Niño events on Darwin's finch productivity. Ecology 81:2442-2457

Henen BT (1997) Seasonal and annual energy budgets of female desert tortoises Gopherus agassizii. Ecology 78:283-296

Henen BT, Peterson CC, Wallis IR, Berry KH, Nagy KA (1998) Effects of climatic variation on field metabolism and water relations of desert tortoises. Oecologia 117:365-373

Hofmeyr MD, Henen BT, Loehr VJT (2005) Overcoming environmental and morphological constraints: egg size and pelvic kinesis in the smallest tortoise, Homopus signatus. Can J Zool 83:1343-1352

IUCN (2006) 2006 IUCN Red List of threatened species. http:// www.iucnredlist.org. Downloaded on 5 Aug 2006

Iverson JB (1992) Correlates of reproductive output in turtles (order Testudines). Herpetol Monogr 6:25-42

Kuchling G (1999) The reproductive biology of the chelonians. Springer, Heidelberg

Lagarde F, Bonnet X, Henen BT, Corbin J, Nagy KA, Naulleau G (2001) Sexual size dimorphism in steppe tortoises (Testudo horsfieldi): growth, maturity, and individual variation. Can J Zool 79:1433-1441 
Le Roux A, Schelpe T (1997) Namaqualand: South African wildflower guide I. Botanical Society of South Africa, Kirstenbosch

Loehr VJT (1999) Husbandry, behavior, and captive breeding of the Namaqualand speckled padloper (Homopus signatus signatus). Chelonian Conserv Biol 3:468-473

Loehr VJT (2002a) Population characteristics and activity patterns of the Namaqualand speckled padloper (Homopus signatus signatus) in the early spring. J Herpetol 36:378-389

Loehr VJT (2002b) Diet of the Namaqualand speckled padloper, Homopus signatus signatus, in early spring. Afr J Herpetol 51:47-55

Loehr VJT (2006) Natural diet of the Namaqualand speckled padloper (Homopus signatus signatus). Chelonian Conserv Biol 5:149-152

Loehr VJT, Henen BT, Hofmeyr MD (2004) Reproduction of the smallest tortoise, the Namaqualand speckled padloper, Homopus signatus signatus. Herpetologica 60:444-454

Loehr VJT, Henen BT, Hofmeyr MD (2006) Shell characteristics and sexual dimorphism in the Namaqualand speckled padloper, Homopus signatus signatus. Afr J Herpetol 55:1-11

Lorenzon P, Clobert J, Oppliger A, John-Alder H (1999) Effect of water constraint on growth rate, activity and body temperature of yearling common lizard (Lacerta vivipara). Oecologia 118:423430

Medica PA, Bury RB, Turner FB (1975) Growth of the desert tortoise (Gopherus agassizi) in Nevada. Copeia 1975:639-643

Peterson CC (1996a) Anhomeostasis: seasonal water and solute relations in two populations of the desert tortoise (Gopherus agassizii) during chronic drought. Physiol Zool 69:1324-1358

Peterson CC (1996b) Ecological energetics of the desert tortoise (Gopherus agassizii): Effects of rainfall and drought. Ecology 77:1831-1844
Pritchard PCH (1993) Carapacial pankinesis in the Malayan softshell turtle, Dogania subplana. Chelonian Conserv Biol 1:31-36

Ricklefs RE (2006) Embryo development and ageing in birds and mammals. Proc R Soc B 273:2077-2082

Rutherford MC, Midgley GF, Bond WJ, Powrie LW, Roberts R, Allsopp J (1999) Plant biodiversity: vulnerability and adaptation assessment. South African country study on climate change. National Botanical Institute, Claremont, South Africa

Shine R, Iverson JB (1995) Patterns of survival, growth and maturation in turtles. Oikos 72:343-348

Stearns SC (1992) The evolution of life histories. Oxford University Press, Oxford

Stenseth NC, Mysterud A (2002) Climate, changing phenology, and other life history traits: nonlinearity and match-mismatch to the environment. Proc Natl Acad Sci USA 99:13379-13381

Tinkle DW (1969) The concept of reproductive effort and its relation to the evolution of life histories of lizards. Am Nat 103:501-516

Van Rooyen MW (1999) Functional aspects of short-lived plants. In: Dean WRJ, Milton SJ (eds) The karoo: ecological patterns and processes. Cambridge University Press, Cambridge, pp 107-122

Visser ME, Van Noordwijk AJ, Tinbergen JM, Lessells CM (1998) Warmer springs lead to mistimed reproduction in great tits (Parus major). Proc R Soc Lond B 265:1867-1870

Weladji RB, Holand O (2003) Global climate change and reindeer: effects of winter weather on the autumn weight and growth of calves. Oecologia 136:317-323

Wikelski M, Thom C (2000) Marine iguanas shrink to survive El Niño. Nature 403:37-38

Zar JH (1999) Biostatistical analysis. Prentice-Hall, Upper Saddle River, NJ 